OPEN ACCESS

Edited by:

Agnieszka Paradowska-Gorycka,

National Institute of Geriatrics,

Rheumatology and Rehabilitation,

Poland

Reviewed by:

Valeria Internò,

University of Bari Aldo Moro, Italy

Sun Jung Kim,

Northwell Health, United States

${ }^{*}$ Correspondence:

Qin Wang

wangqin78@suda.edu.cn

ZhongWen Sun

zhwsun@szhct.edu.cn

Specialty section:

This article was submitted to

Autoimmune and

Autoinflammatory Disorders,

a section of the journal

Frontiers in Immunology

Received: 22 February 2021 Accepted: 02 June 2021

Published: 21 June 2021

Citation:

Fu N, Xie F, Sun Z and Wang Q (2021) The OX40/OX40L

Axis Regulates $T$ Follicular Helper

Cell Differentiation: Implications

for Autoimmune Diseases.

Front. Immunol. 12:670637. doi: 10.3389/fimmu.2021.670637

\section{The OX40/OX40L Axis Regulates T Follicular Helper Cell Differentiation: Implications for Autoimmune Diseases}

\author{
NanNan Fu ${ }^{1}$, Fang Xie ${ }^{1}$, ZhongWen Sun ${ }^{2 *}$ and Qin Wang ${ }^{1 *}$ \\ ${ }^{1}$ School of Biology \& Basic Medical Sciences, Medical College of Soochow University, Suzhou, China, ${ }^{2}$ Department of \\ Medical Technology, Suzhou Vocational Health College, Suzhou, China
}

T Follicular helper (Tfh) cells, a unique subset of $C D 4^{+} \mathrm{T}$ cells, play an essential role in B cell development and the formation of germinal centers (GCs). Tfh differentiation depends on various factors including cytokines, transcription factors and multiple costimulatory molecules. Given that OX40 signaling is critical for costimulating T cell activation and function, its roles in regulating Tfh cells have attracted widespread attention. Recent data have shown that OX40/OX40L signaling can not only promote Tfh cell differentiation and maintain cell survival, but also enhance the helper function of Tfh for B cells. Moreover, upregulated OX40 signaling is related to abnormal Tfh activity that causes autoimmune diseases. This review describes the roles of OX40/OX4OL in Tfh biology, including the mechanisms by which OX40 signaling regulates Tfh cell differentiation and functions, and their close relationship with autoimmune diseases.

Keywords: OX40, OX40L, Tfh cells, differentiation, autoimmune diseases

\section{INTRODUCTION}

Many autoimmune diseases such as systemic lupus erythematosus (SLE) and rheumatoid arthritis (RA) are characterized by autoantibody production. A specialized cell subset named T follicular helper (Tfh) cells has attract much attention because of their requirement for B cell help and the production of high affinity class-switched antibodies. Tfh cells, located in lymphoid follicles, belong to a distinct $\mathrm{CD}^{+} \mathrm{T}$ subset. They are essential for generation of effective and long-lived humoral immune responses. Several pairs of costimulatory molecules have been demonstrated to control Tfh development and function. OX40/OX40L is one of them. OX40 and OX40L play a critical role in enhancement of immune responses and participate in the development of autoimmune diseases. Recently, it was reported that the OX40/OX40L interaction is required for the functions of Tfh cells. This article focuses on the effects of OX40/OX40L signaling on Tfh cells and their roles in the pathogenesis of autoimmune diseases. 


\section{DIFFERENTIATION AND FUNCTIONS OF Tfh CELLS}

In 2000, Schaerli and Breifeld found that there is a subset of $\mathrm{CD}^{+}{ }^{+} \mathrm{T}$ cells in lymphoid follicles, called Tfh cells, which express CXCR5, ICOS and CD40L (1). They are obviously distinct from other Th cells in two aspects. First, while CXCR5 is only expressed temporarily on other Th cell subpopulations when they are activated, while its expression on Tfh cells persists for a long time. Upregulated CXCR5 and downregulated CCR7 facilitate the migration of $\mathrm{Tfh}$ cells from the $\mathrm{T}$ cell area to CXCL13-rich B lymphoid follicles where they interact with B cells. Second, unlike Th1, Th2 and Th17 cells, the differentiation of Tfh cells proceeds through multiple stages, including initiation, maintenance and full polarization. A variety of cytokines, transcription factors and surface molecules are involved in these process (2-4).

ICOS, PD-1, Bcl-6, BTLA, CD40L, IL-21, IL-6R, SAP and IL$21 \mathrm{R}$ are shown to be highly expressed in mouse and human Tfh cells, indicating that these molecules may play critical roles in promoting the development and maintenance of Tfh cells and regulating their functions (4-7). Bcl-6 is recognized as an essential transcription factor for regulation of $\mathrm{Tfh}$ cell differentiation. Bcl6 controls Tfh differentiation by antagonizing Blimp-1 and other transcription factors which are also important for Th1, Th2 and Th17 cells. GCs are absent in Bcl-6-deficient mice since Bcl-6 deficient $\mathrm{CD}^{+}{ }^{+} \mathrm{T}$ cells do not support the GC reaction. The expression of Bcl-6 in Tfh cells is mainly driven by IL- 6 , IL- 21 and certain downstream transcription factors including STAT1 and $\operatorname{STAT3}(8,9)$. Recently, a feed-forward loop mediated by the transcription factors Bcl-6 and Tox 2 is reported to promote the Tfh program (10). Bcl-6 upregulates Tox2 expression, which further drives Bcl-6 expression and Tfh development. ICOS/ ICOSL molecules are involved in every stage of Tfh cell differentiation. Mathieu et al. transferred ICOS-Y181F into mice to block ICOS-mediated PI3K activation and found that the number of Tfh cells in the spleen was significantly reduced. At the same time, ICOS-PI3K was also found to be essential for upregulating IL-21 and IL-4, which are key factors for Tfh function $(4,11)$. These multiple factors drive Tfh differentiation. The first stage of Tfh differentiation is initiated by interaction with a professional antigen-presenting cell (APC), such as a dendritic cell (DC). After T cell priming, Bcl-6 and CXCR5 expression is upregulated on $\mathrm{CD}^{+}{ }^{+} \mathrm{T}$ cells to facilitate Tfh cell migration to the T-B border. Then, the second stage begins. This is a B cell-dependent phase of Tfh differentiation that is regulated by ICOS/ICOSL signaling. In the third stage, Tfh cells and B cells migrate to GCs, where B cells continuously help Tfh cells to promote their full polarization. GC Tfh cells are in a further polarized Tfh cell state, with elevated expression of Bcl-6, CXCR5, PD-1 and ICOS.

The most important function of Tfh cells is to provide help to B cells (12). They are necessary for GC formation, high-affinity B cell selection, and generation of memory B cells and plasma cells $(13,14)$. At the T-B border, B cells present antigens to Tfh cells and only those cells presenting antigens with high affinity obtain Tfh help and then enter GCs (15). Most B cell responses cannot progress without the help of Tfh cells. GCs are recognized as the essential sites of $\mathrm{B}$ cell mutation and antibody affinity maturation. After GC Tfh cells recognize the antigens presented by GC B cells in the follicle light zone, they provide signals for GC B cell proliferation and migration to the dark zone, where B cells will undergo somatic hypermutation (16). Moreover, GC Tfh cells promote the development of long-term humoral immunity by generating memory B cells and highaffinity plasma cells. The effect of Tfh cells on B cell differentiation within GCs and extrafollicular areas depends on numerous signals, such as IL-21 and CD40 signals. IL-21 is the most potent cytokine driving plasma cell differentiation in both mice and humans (17-21). IL-21 induces both Bcl-6 and Blimp-1 expression in B cells, in which Bcl-6 promotes GC B cell proliferation and Blimp-1 is critical for plasma cell differentiation $(17,22,23)$. IL-21 signaling is dependent on the activation of STAT3 and STAT5 (24). CD40L/CD40 engagement is central to the maintenance of GC B cells. Provision of CD40L protein in vitro was found to inhibit apoptosis of GC B cells (2527). Schirock et al. reported that a critical ECM: $\alpha_{v}$ integrin axis specifically regulated prolonged Tfh positioning within the GCs and supported the generation of long-lived plasma cells but not memory B cells (28).

\section{OX40 AND OX40L MOLECULES}

\section{Structure and Expression of OX40 and OX40L}

OX40 (also called ACT35, CD134 or TNFRSF4), belonging to the TNFR superfamily, is a type 1 transmembrane protein containing 249 amino acids with a 49 amino acids in cytoplasmic tail and a 186 amino acids in extracellular region $(29,30)$. OX40 protein was first recognized on activated rat CD $4^{+}$ $\mathrm{T}$ cells in 1987. Subsequently, OX40 expression was also found expressed in mice and humans (31-33). OX40 is mainly expressed on activated $\mathrm{CD} 4^{+} \mathrm{T}$ cells and $\mathrm{CD} 8^{+} \mathrm{T}$ cells, whereas its expression level is relatively low on NK cells and NKT cells (29, 34-37). OX40L (also named as CD252, TNFSF4, CD134L or gp34), the ligand of OX40, is a type II glycoprotein with a 23 amino acids cytoplasmic tail and a 133 amino acids extracellular domain (38). As a member of the TNF superfamily, it is expressed as a trimer. OX40L was initially identified as gp34 protein on human T-cell leukemia virus transformed cells in 1985 (39). Later, it was found that OX40L is mainly expressed on antigen presenting cells, such as B cells and dendritic cells (40-42). Similar to other members of the TNF family, the OX40 signal transduces through TNF receptor related factors (TRAFs). OX40 signal is transduced to T cells via TRAF2 and TRAF5 in vivo and TRAF1, TRAF3 and TRAF5 in vitro (43-47).

The expression of OX40 and OX40L is regulated by many factors. OX40 expression is induced on T cells by TCR, CD28/ CD80, CD40/CD40L and other signals and peaks at 48-72 hours following $\mathrm{T}$ cell activation $(34,48-50)$. TCR signaling can initiate 
the expression of OX40 on a variety of cells, while CD28 and other cytokines can further promote its expression on activated $\mathrm{T}$ cells (32). It has also been reported that IL-2, IL-4 and TNF can enhance or prolong OX40 expression. Sun et al. found that IL-2, TNF- $\alpha$ and IFN- $\gamma$ were highly expressed in liver tissues of animal models of nonalcoholic steatohepatitis, but only exogenous IL-2 stimulation could upregulate OX40 expression on CD4 ${ }^{+} \mathrm{T}$ cells (51). CD40 signaling and inflammatory signals transmitted by Toll-like receptors induce OX40L expression on antigenpresenting cells (41). Factors such as IL-18, IFN- $\gamma$, thymic stromal lymphopoietin (TSLP) and prostaglandin E2 can also promote the expression of OX40L (49, 52-55). In an inflammatory environment, upregulated OX40L expression on APCs ensures that activated $\mathrm{OX} 40^{+} \mathrm{T}$ cells receive OX40 signals from nearby cells (33).

\section{Functions of OX40 and OX40L}

As a pair of costimulatory molecules, OX40/OX40L is required for $\mathrm{T}$ cell activation especially in the later phase of the immune response. OX40/OX40L plays critical roles in enhancing the function of effector $\mathrm{T}$ cells, maintaining their survival and inhibiting their apoptosis. Rogers et al. detected a significantly decreased percentage of antigen-specific $\mathrm{T}$ cells in OX40deficient mice. Moreover, antiapoptotic molecules, such as Bcl$\mathrm{xL}$ and $\mathrm{Bcl}-2$, were obviously downregulated in $\mathrm{OX} 40^{-/-} \mathrm{T}$ cells and CD $28^{-1-} \mathrm{T}$ cells after antigen stimulation. When CD $28^{-1-} \mathrm{T}$ cells were stimulated with an anti-OX40 agonist antibody, the expression of $\mathrm{Bcl}-\mathrm{xL}$ and $\mathrm{Bcl}-2$ was increased, and $\mathrm{T}$ cell apoptosis was inhibited (56). OX40-deficient $\mathrm{T}$ cells normally proliferated and differentiated into effector T cells 2-3 days after activation of TCR signaling. However, the survival rate was significantly reduced after 12-13 days of activation, which indicated that OX40 signaling might not be essential for the early stage of $\mathrm{T}$ cell activation but might promote the proliferation of $\mathrm{T}$ cells and maintain their survival in the later stage (57). OX40/OX40L signaling is critical for differentiation of various Th cells. This signaling preferentially induces differentiation of naive $\mathrm{CD}^{+} \mathrm{T}$ cells into $\mathrm{Th} 2$ cells but promotes Th1 differentiation under the influence of antigens or IL-12 (58). OX40 was also reported to play important roles in differentiation of Th9 cells through the nonclassical NF- $\mathrm{KB}$ pathway by activating tumor necrosis factor receptorassociated factor 6 (TRAF6) (59). Which type of Th cell differentiation is promoted by this signal may be dependent on the environment it is involved. OX40 expression is usually downregulated after the effect phase of the primary $\mathrm{T}$ cell response and can be rapidly upregulated on memory $\mathrm{T}$ cells after secondary challenge with the same antigen again to subsequently activate and recruit memory effector $\mathrm{T}$ cells, suggesting that the OX40/OX40L interaction is required in the recall response (59). OX40 is also constitutively expressed on mouse Treg cells (60). Evidence has shown that OX40 signaling is essential for inhibiting Treg cell function. Jaquemin et al. reported that engagement of the OX40/OX40L axis resulted in Foxp3 downregulation in Tregs and decreased Treg-mediated suppression of effector $\mathrm{T}$ cell proliferation(OX40 upregulates BATF3 and BATF, which produce a closed chromatin configuration to repress Foxp3 expression in a Sirt1/7dependent manner (61). However, there are also reports showing that OX40 agonists can enhance Treg cell proliferation and inhibit function. Gavin MA et al. found that the number of Treg cells in the spleen of OX40-deficient mice decreased, while the number of Treg cells in the thymus of OX40L-overexpressing mice increased, indicating that abnormal OX40/OX40L signaling interfered with the development of Treg cells (62).

In addition to its critical role in $\mathrm{T}$ cells, OX40/OX40L signaling can also promote the differentiation and maturation of DCs. Human immature DCs have no OX40L expression, whereas the expression of OX40L is rapidly induced after sCD40L stimulation. Ligation of OX40L upregulated the expression of CD80, CD86, CD54 and CD40 on mononuclearderived DCs in the reversible phase, and could enhance the secretion of IL-4, IL- 6 , IL-12, TNF- $\alpha$ and IL- $1 \beta$ by 4 - to 35 - fold (41). This result indicates that the $\mathrm{OX} 40 \mathrm{~L}$ reverse signal enhanced the maturation of DCs. B cells are also an OX40Lexpressing antigen-presenting cells that play an important role in formation of the GC (63). Cross-linking of OX40L on stimulated $B$ cells significantly enhanced proliferative response and promoted immunoglobulin secretion (64). Morimoto et al. found CD134L engagement on human B cells increased IgG production rate per cell rather than increasing the number of plasma cells (65). Therefore, the OX40/OX40L bidirectional signal not only acts on $\mathrm{T}$ cells but also plays critical roles in differentiation and maturation of APCs, especially DCs and B cells (Table 1).

\section{OX40/OX40L SIGNALING IN Tfh CELLS}

\section{Expression of OX40 On Tfh Cells}

OX40 is transiently expressed on $\mathrm{CD}^{+} \mathrm{T}$ cells after 12-24 hour of activation. As a distinct $\mathrm{CD} 4^{+} \mathrm{T}$ cell subset, Tfh cells in both mice and humans have been confirmed to express OX40.

TABLE 1 | OX40/OX40L functions in different cell types.

\begin{tabular}{|c|c|c|}
\hline $\begin{array}{l}\text { Cell } \\
\text { types }\end{array}$ & $\begin{array}{l}\text { OX40 or OX40L } \\
\text { expression }\end{array}$ & Functions \\
\hline T cells & OX40 and OX40L & $\begin{array}{l}\text { Promotion of T cell activation and proliferation } \\
\text { (57) } \\
\text { Inhibition of T cell apoptosis }(56) \\
\text { Enhancement of recall response }(59) \\
\text { Promotion of Th differentiation }(58,59)\end{array}$ \\
\hline Tfh cells & OX40 & $\begin{array}{l}\text { Promotion of Tfh differentiation and } \\
\text { maintenance } \\
\text { Enhancement of Tfh function of helping } \\
\text { B cells }\end{array}$ \\
\hline Tregs & OX40 & $\begin{array}{l}\text { Inhibition of Treg function }(60,61) \\
\text { Promotion of Treg proliferation (62) }\end{array}$ \\
\hline DCs & OX40L & $\begin{array}{l}\text { Promotion of the differentiation and } \\
\text { maturation of DCs (41) }\end{array}$ \\
\hline B cells & OX40L & $\begin{array}{l}\text { Promotion of B cell proliferation and lg } \\
\text { secretion }(64,65) \\
\text { Promotion of GC formation (63) }\end{array}$ \\
\hline
\end{tabular}


Adam L et al. found that OX40 and ICOS were coexpressed on peripheral blood Tfh cells of patients with primary biliary cholangitis (PBC) and primary sclerosing cholangitis (PSC). Compared with $\mathrm{PBC}$ patients, PSC patients had significantly upregulated OX40 and ICOS expression (66). Analysis of patients with rheumatoid arthritis (RA) showed an abundance of OX40-overexpressing Tfh cells, especially Tfh17 cells (67). Jiang et al. also reported OX40 expression on Tfh cells in a mouse model of myelodysplastic syndrome (MDS) (68). Tahiliani et al. found that in mice infected with vaccinia virus, OX40 was already expressed on pre-Tfh cells, and the expression level gradually increased with maturation of the Tfh cells (69). Therefore, OX40 is expressed during differentiation of Tfh cells and may play a role in Tfh development and functions.

\section{Differentiation and Maintenance of Tfh Cells}

Many cytokines and costimulatory signals, such as IL-12, IL-6 and ICOS/GL50, have been reported as the key factors in differentiation of Tfh cells. Recently, OX40/OX40L is characterized as another important costimulatory signal to promote Tfh differentiation. It has been reported that Rouqin regulates Tfh cell differentiation by inhibiting the expression of ICOS and OX40 mRNA, suggesting a close correlation between OX40 and Tfh cells (70). Defects in Rc3h1 and Rc3h2 in T cells elevate the expression of OX40 and Irf4, leading to activation of the NF- $\kappa \mathrm{B}$ pathway. Tfh cells and GC-B cells spontaneously differentiate in the absence of immunization (70). Therefore, OX40 may promote the differentiation of Tfh cells.

CXCR5 is one of the most widely used markers to identify Tfh cells. Initially, OX40 in vitro was reported to induce CXCR5 mRNA transcription in activated mouse $\mathrm{T}$ cells, indicating that OX40 signaling may promote differentiation of Tfh cells by upregulating CXCR5 expression $(71,72)$. Then, the OX40/ OX40L signal was found to upregulate multiple Tfh genes, including CXCR5, Bcl-6, IL-21, CXCL13 and PDCD1, in both naïve and memory Th cells and to downregulate the expression of the transcription factor PRDM1, which inhibited the generation of Tfh cells (72). The upregulation of Bcl-6 and downregulation of PRDM1 fully demonstrated the important role of OX40 signaling in Tfh cell differentiation. Jacquemin et al. further compared the expression of Tfh genes after stimulation with OX40, IFN- $\gamma$ and IL-12 which is an inducer of Tfh cells, and found that OX40 and IL-12 promoted naïve Th cells to express Tfh cell-related genes at similar levels (72). OX40 signaling is more efficient than IL-12 signaling at inducing memory Th cells to upregulate Tfh genes. The cooperation of the two signals can further increase the expression of CXCR5 and $I L-21$ on memory Th cells. In addition, it was shown that after 8-15 days of infection with vaccinia virus $(\mathrm{VacV})$ in $\mathrm{OX} 40$-deficient mice, the numbers of Tfh and GC Tfh cells were significantly reduced compared with those in wild-type mice, indicating a critical role of OX40 in Tfh maturation (69). Prior studies reported that the interaction of OX40 and OX40L can also promote accumulation of $\mathrm{CD}^{+}{ }^{+} \mathrm{T}$ cells in the $\mathrm{T} / \mathrm{B}$ boundary and $\mathrm{B}$ cell follicles in mouse models with protein Ag immunization (73). Recently, Tahiliani V et al. visualized OX40L-expressing DCs and $\mathrm{B}$ cells at the T/B borders and in the follicle and GC, in direct association with $\mathrm{OX} 40^{+} \mathrm{Tfh}$ cells in these areas (69). The interaction between Tfh cells and DCs or B cells is very important for further Tfh differentiation and Tfh maintenance. Therefore, OX40/OX40L signaling promotes not only Tfh generation but also Tfh maturation and maintenance (Figure 1).

\section{Enhancement of Tfh Functions}

OX40L was found to be expressed in the GCs and surrounding areas, suggesting that OX40/OX40L signaling may play a role in formation of the GC. Li Y et al. constructed a recombinant rabies virus (RABV) mouse model (LBNSE-OX40L) which overexpressed OX40L and found that Tfh cells and GC-B cells significantly increased after RABV infection (74). Deletion of OX40L in B cells in the SLE mouse model resulted in an improved disease index and a decreased number of plasma cells and GC-B cells (75). In OX40-deficient mice, GCs could not be built up even if activated $B$ cells from wild-type mice were injected. In contrast, GCs could be formed and expanded when B cells from OX40-deficient mice were injected into wild-type mice (69), suggesting that the OX40/OX40L signal is essential for the formation of GCs. In addition, reduced $\mathrm{Ab}$ production has been found in animals that lack the OX40 molecule. The interaction of $\mathrm{OX}_{40 \mathrm{~L}^{+}} \mathrm{B}$ cells and $\mathrm{OX} 40^{+}$Tfh cells has been observed in T-B border and GCs in mice infected with $\mathrm{VacV}$, further indicating the roles of OX40/OX40L signaling in Tfh helping B cells. During their interaction, a bidirectional OX40/OX40L signal occurs. On the one hand, OX40 on Tfh cells can receive signals from OX40L expressed on B cells to promote secretion of cytokines such as IL21, which further assists B cell activation and antibody production. On the other hand, B cells can receive the OX40L reverse signal from $\mathrm{Tfh}$ to directly expand $\mathrm{B}$ cell clones and promote GC formation (Figure 1).

\section{OX40-Initiated Signaling Pathways in Tfh Cells}

There are two main OX40/OX40L signal transduction pathways in $\mathrm{T}$ cells. One is the antigen-independent NF- $\mathrm{KB}$ pathway, and the other is the antigen-dependent PI3K-Akt pathway. Binding of OX40L results in trimerization of OX40 monomers and recruitment of TRAF2, 3 and $5(46,47)$. TRAF2 has been characterized as an adaptor molecule that can lead to activation of NF- $\kappa B$ signal and recruitment of PI3K. For the NF- $\kappa B$ pathway, engagement of OX40 on activated/effector T cells by OX40L recruits not only the TRAF-RIP-IKK $\alpha / \beta / \gamma$ complex, but also the PCARMA1-BCL10-MALT1-PKC $\theta$ complex (76). This signalosome directly controls NF- $\kappa \mathrm{B}$ activation without antigen/ TCR engagement. The TRAF-RIP-IKK $\alpha / \beta / \gamma$ signaling complex mediates phosphorylation and degradation of $\mathrm{I} \kappa \mathrm{B} \alpha$, leading to activation of NF- $\mathrm{\kappa B} 1$ and entry of p50 and RelA into the nucleus, which is sufficient to provide survival signals to $\mathrm{T}$ cells in the absence of antigens. The CARMA1-MALT1-BCL10-PKC $\theta$ complex forms the signalosome with OX40 in the immune synapse, which plays a major role in promoting prolonged NF- $\kappa B$ activity and survival of effector $\mathrm{T}$ cells during late-phase $\mathrm{T}$ cell 


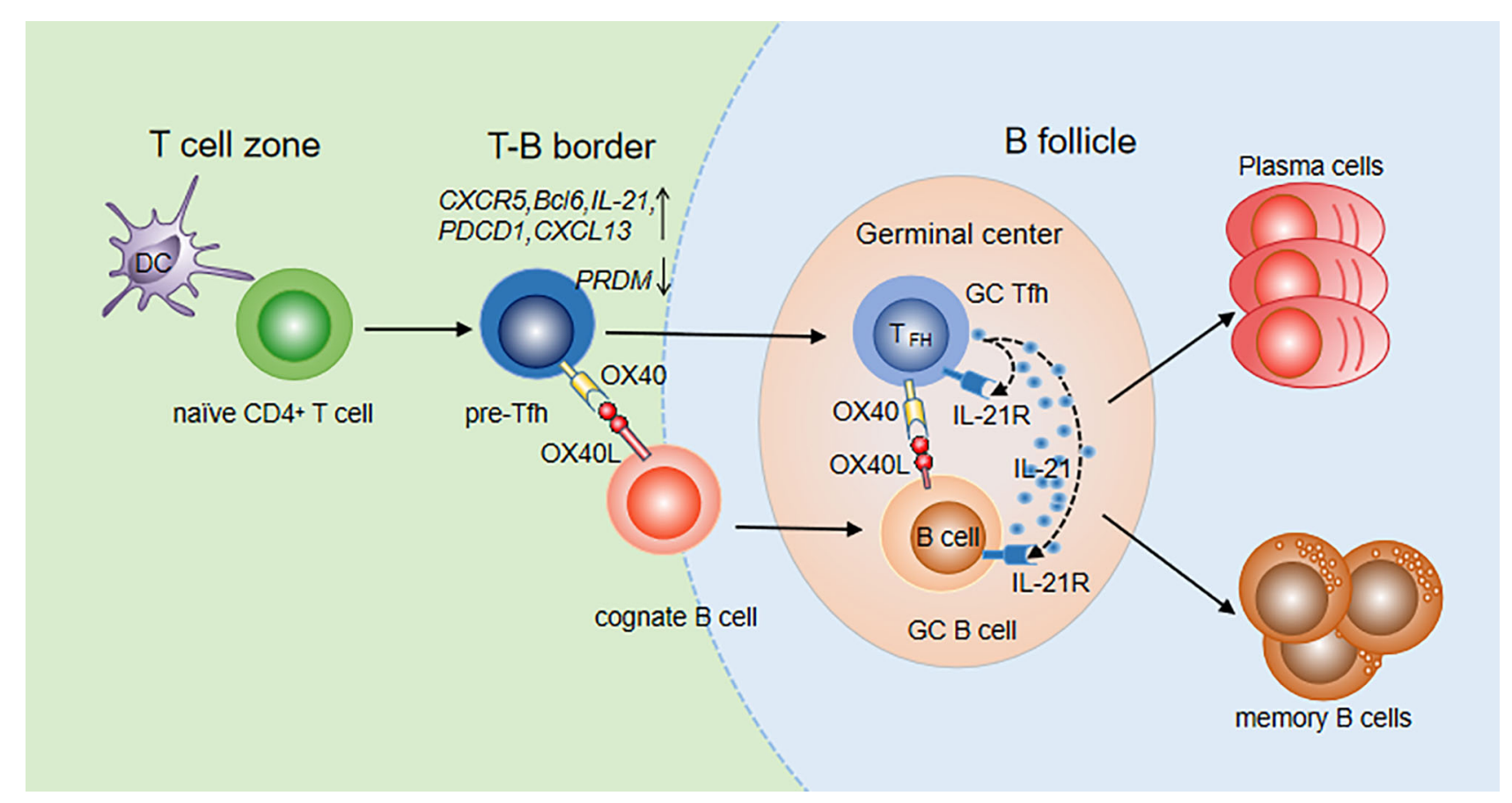

FIGURE 1 | OX40/OX4OL signaling in Tfh differentiation and function. Tfh differentiation occurs at the time of DC priming. Upregulation of OX40 on pre-Tfh cells promotes their accumulation at the T-B border. With the interaction of cognate B cells, OX40 signaling contributes to Tfh maintenance, maturation and migration to B follicles. Meanwhile, B cells also move to B follicles to further interact with Tfh cells. Bidirectional OX40/OX40L signaling promotes both GC Tfh and GC B cell differentiation. With the help of GC Tfh cells, B cells differentiate into plasma cells and memory cells.

responses when antigen is cleared. OX40 can also induce phosphorylation of IKK $\alpha$ and activation of NIK, which activates the noncanonical NF- $\kappa B 2$ pathway $(46,77,78)$. For the PI3K-Akt pathway, after ligation of OX40L, OX40 was found to assemble a signaling complex that contains TRAF2, PKB and its upstream activator PI3K $(79,80)$. It only induced strong phosphorylation and functional activation of the PI3K-Akt pathway when Ag was presented. Thus, OX40 can augment TCR signaling via the PI3KAkt pathway. In addition, OX40 synergizes with TCR to allow $\mathrm{Ca}^{2+}$ influx and nuclear accumulation of NFATc1 and NFATc2 (78) (Figure 2).

The NF- $\kappa \mathrm{B}$ pathway is also involved in Tfh cell proliferation and survival (81). Blocking molecules in the NF- $\mathrm{KB} 1$ and NF$\kappa \mathrm{B} 2$ pathways inhibits the Bcl- 6 expression on $\mathrm{CD}^{+} \mathrm{T}$ cells. However, the effect is independent of OX40 signaling (72). Strong and durable TCR signals can also contribute to promoting Th cell differentiation to the Tfh lineage and their proliferation (82-84). A recent study showed that stimulation with anti-CD3 and anti-CD28 beads promoted the expression of multiple Tfh molecules including CXCR5, IL-21, CD40L and Bcl-6, in a dose-dependent manner. The combination of OX40 and TCR signals further upregulated the expression of Tfh molecules, indicating that OX40 signaling promotes Tfh differentiation by enhancing TCR signaling. PI3K activity is an essential component of pathways driving Tfh cell and GC formation (85). Both TCR and OX40 are characterized as strong activators of both the PI3K and Akt signaling pathways.
Thus, OX40 may mediate Tfh cells by augmenting TCR signaling via the PI3K-Akt pathway. Another way for OX40 to regulate Tfh cells may be through NFAT, which has been shown to be essential for effective Tfh development (Figure 2) (86).

\section{IMPLICATION OF Tfh IN AUTOIMMUNE DISEASES AND IMMUNE THERAPY THROUGH OX40/OX40L SIGNALING}

Tfh cells and OX40/OX40L have both been reported to be associated with autoimmune diseases both in humans and mice (Table 2). Since many autoimmune diseases such as SLE, RA and Graves' diseases are autoantibody-mediated, the critical roles of Tfh cells in these diseases are obvious (87-101). Tfh cells enhance the intensity and duration of the GC response and promote autoantibody production. In lupus nephritis lesions, Tfh-like cells expressing PD-1, ICOS, IL-21 and Bcl-6 were observed to form ectopic GCs. In addition, an increased population of circulating Tfh cells was identified in SLE patients (102). In salivary gland tissues and peripheral blood of patients with Sjogren's syndrome (SS), the numbers of $\mathrm{CD} 4^{+} \mathrm{CXCR} 5^{+} \mathrm{Tfh}$ cells were significantly increased along with abnormal B cells and plasma cells, suggesting that Tfh cells participate in the pathogenesis of SS by promoting B cell maturation (103). Moreover, multiple studies have demonstrated that OX40 is expressed on pathogenic $\mathrm{T}$ cells in autoimmune 


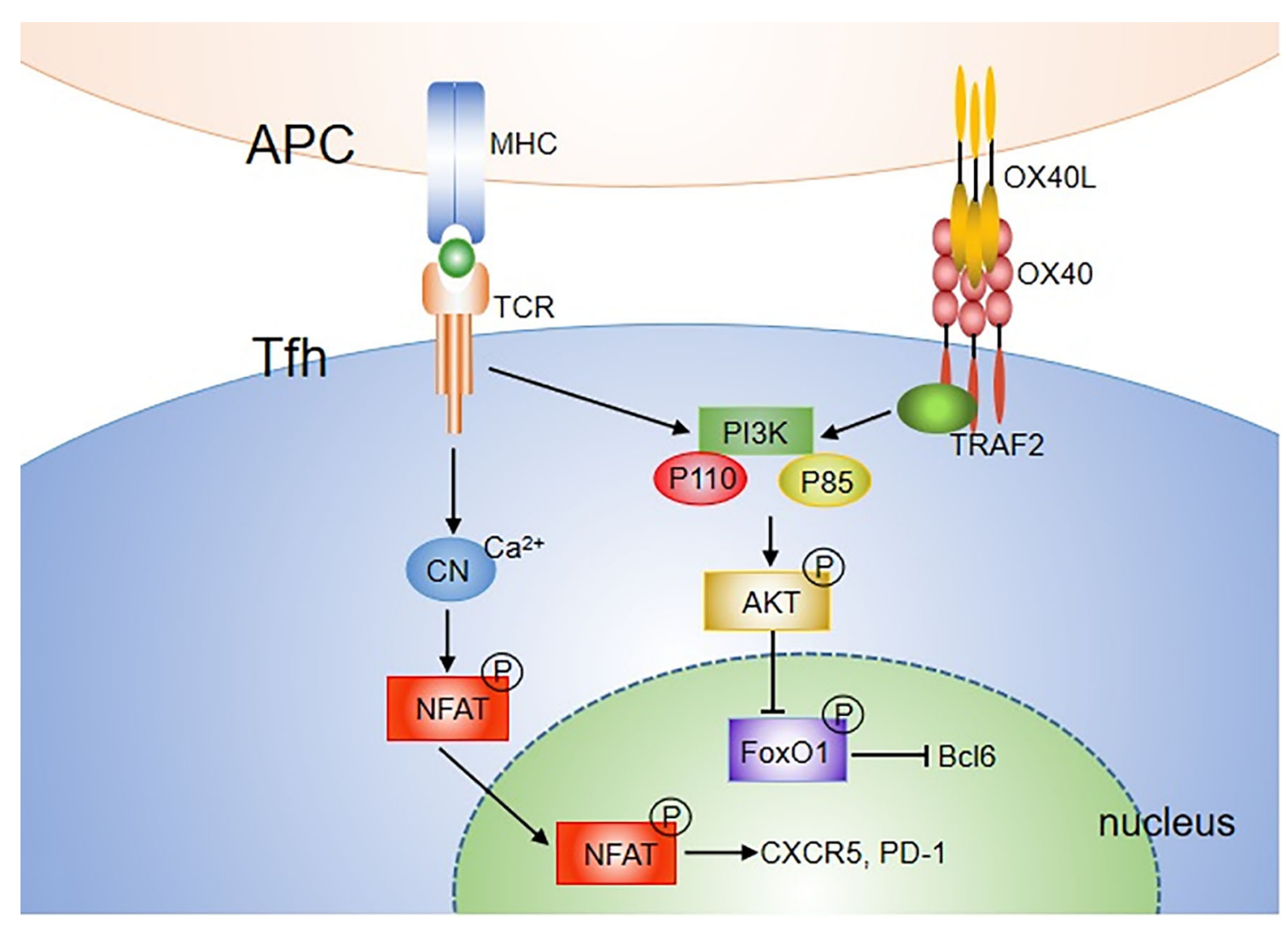

FIGURE 2 | OX40 signaling pathways mediating Tfh differentiation. Both TCR and OX40 can activate PI3K, including P110 and P85 subunit, further leading to phosphorylation of AKT. PAKT then phosphorylates the FOXO1 transcription factor, which can subsequently be exported out of the nucleus and degraded. FOXO1, which represses Bcl6, is recognized as an inhibitor of Tfh differentiation. In addition, OX40 synergizes with TCR to allow Ca ${ }^{2+}$ influx and nuclear accumulation of NFATc1 and NFATc2. Overall, OX40 may mediate Tfh cell activity by augmenting TCR signaling via the NFAT or PI3K-Akt pathway.

disease $(42,104-112)$. Farres et al. found that compared with healthy people, $\mathrm{CD}^{+} \mathrm{T}$ cells in SLE patients express high levels of OX40, and the disease activity index is positively correlated with the number of $\mathrm{CD}^{+} \mathrm{T}$ cells expressing OX40. The disease is improved after treatment with an anti-OX40L monoclonal antibody $(113,114)$. Yoshioka et al. found that $\mathrm{T}$ lymphocytes in synovial fluid and synovial tissue of RA patients express OX40, and secondary lymphocytes in synovial tissue express OX40L, suggesting that the OX40/OX40L interaction may play a key role in RA occurrence and development (34). Graves' disease (GD) is an autoimmune thyroid disease, with clinical manifestations that primarily include ophthalmopathy, goiter and hypermetabolic syndrome $(115,116)$. We have found that OX40/OX40L was abnormally and persistently coexpressed on $\mathrm{CD}^{+}{ }^{+} \mathrm{T}$ cells from GD patients, and the coexpression level was closely related to TRAb (117).

Recent data for SLE and RA showed that high OX40 and OX40L expression may be involved in the pathogenesis of autoimmune diseases by enhancing Tfh functions. Jacquemin et al. also reported that $\mathrm{OX} 40 \mathrm{~L}^{+}$myeloid cells are visualized in skin and kidney tissues from SLE patients. OX40 engagement upregulated the expression of several Tfh-associated molecules in
T cells from lupus patients, including Bcl6, CXCR5 and IL-21, showing that Th cells in an OX40L-rich environment may receive OX40 signaling to promote $\mathrm{Tfh}$ development. The percentage of OX40L $\mathrm{L}^{+}$myeloid cells in blood was significantly higher in active patients than in inactive patients and positively correlated with peripheral Tfh cell frequencies, indicating that the Tfh response was enhanced by the OX40 signal. Moreover, myeloid cells expressing OX40L can also impair Treg and Tfr functions by suppressing Tfh-dependent B cell activation and immunoglobulin secretion in SLE. OX40-overexpressing Tfh cells, especially Tfh 17 cells, were found to be increased in RA and a murine model. In vitro coculture experiments showed enhanced hyposialylation by the Tfh cells via OX40. Blockade of OX40 signaling prevented arthritis development by reducing Tfh 17 cells and recovering autoantibody salivation (67). Therefore, upregulated OX40 signaling plays a crucial role in the development of autoimmune diseases by enhancing Tfh functions directly or indirectly. Thus, targeting OX40/OX40L signaling may be an effective strategy for these diseases.

OX40/OX40L blockade in vivo is generally effective in many models with autoimmune diseases, mainly by inhibiting activation and migration of $\mathrm{CD} 4^{+} \mathrm{T}$ cells and altering cytokine 
TABLE 2 | OX40, OX40L expression and Tfh cells in autoimmune diseases.

\begin{tabular}{|c|c|c|c|}
\hline Disease & OX40 & OX40L & Tfh \\
\hline $\begin{array}{l}\text { Systemic lupus } \\
\text { erythematosus } \\
\text { (SLE) }\end{array}$ & $\begin{array}{l}\text { Upregulated OX40 expression on peripheral } \\
\text { T cells (108) }\end{array}$ & $\begin{array}{l}\text { Upregulated OX40L expression on myeloid } \\
\text { APCs (72) }\end{array}$ & $\begin{array}{l}\text { Increased Tfh in patients with active } \\
\text { SLE (108) }\end{array}$ \\
\hline $\begin{array}{l}\text { Rheumatoid arthritis } \\
\text { (RA) }\end{array}$ & $\begin{array}{l}\text { Upregulated OX40 expression on T cells in synovial } \\
\text { fluid and blood }(34,67,119) \\
\text { Upregulated OX40 expression on circulating } \\
\text { CD4 }{ }^{+} \text {CD28- T cells }(116) \\
\text { Upregulated OX40 expression on circulating Tfh17 } \\
\text { cells (67) }\end{array}$ & $\begin{array}{l}\text { Upregulated OX40L expression on sublining } \\
\text { cells in synovial tissue (34) and on } \\
\text { monocytes and B cells in blood (90) }\end{array}$ & $\begin{array}{l}\text { Increased circulating Tfh cells and Tfh17 } \\
\text { cells (118) }\end{array}$ \\
\hline $\begin{array}{l}\text { Type } 1 \text { Diabetes } \\
\text { (T1D) }\end{array}$ & $\begin{array}{l}\text { Increased circulating CD4 }{ }^{+} \mathrm{CD} 25^{\text {high }} \mathrm{OX} 4 \mathrm{O}^{+} \mathrm{T} \text { cells in } \\
\text { children with newly diagnosed T1D (94) }\end{array}$ & & $\begin{array}{l}\text { Increased circulating Tfh cells in newly } \\
\text { diagnosed T1D children (102) } \\
\text { Increased circulating Tfh cells in T1D } \\
\text { patients }(88,89)\end{array}$ \\
\hline Graves' diseases & Upregulation of OX40 on circulating CD4 ${ }^{+}$T cells (117) & $\begin{array}{l}\text { Upregulation of OX40L on circulating } \mathrm{CD}^{+} \mathrm{T} \\
\text { cells (117) }\end{array}$ & $\begin{array}{l}\text { Increased circulating Tfh and Tfh2 } \\
\text { cells }(90) \\
\text { Elevated Tfh cells in thyroid tissues } \\
(77,78)\end{array}$ \\
\hline Multiple sclerosis & $\begin{array}{l}\text { Downregulation of OX40 expression on circulating } \\
\mathrm{CD} 4^{+} \mathrm{T} \text { cells after treatment with natalizumab (95) } \\
\text { The presence of OX40+ } \mathrm{T} \text { cells in brain tissue (106) }\end{array}$ & & $\begin{array}{l}\text { Increased circulating IL-21-producing } \\
\text { Tfh-like cells (96) } \\
\text { Increased Tfh/Tfr ratio associates with } \\
\text { abnormal lgG production in blood and } \\
\text { CSF (92) }\end{array}$ \\
\hline Myasthenia gravis & $\begin{array}{l}\text { Upregulation of OX40 expression on circulating CD4 } \\
\text { T cells (107) and thymic CD4 }{ }^{+} \mathrm{T} \text { cells adjacent to GC } \\
\text { (108). }\end{array}$ & $\begin{array}{l}\text { The presence of } \mathrm{OX}_{40 \mathrm{~L}^{+}} \text {mononuclear cells } \\
\text { in thymic GC (108). }\end{array}$ & $\begin{array}{l}\text { Increased circulating Tfh cells (102) } \\
\text { Increased circulating Tfh17 cells in } \\
\text { MuSK-antibody positive patients (93). }\end{array}$ \\
\hline Sjogren syndrome & $\begin{array}{l}\text { Upregulation of OX40 expression on circulating CD4+ } \\
\text { T cells (108) }\end{array}$ & $\begin{array}{l}\text { Upregulation of OX40L expression on } \\
\text { circulating B cells and monocytes (108) }\end{array}$ & $\begin{array}{l}\text { Increased circulating Tfh and Tfh17 } \\
\text { cells (94) } \\
\text { Localization of Tfh cells in salivary } \\
\text { glands (95) }\end{array}$ \\
\hline lupus mouse & $\begin{array}{l}\text { Upregulation of OX40 expression on CD4 }{ }^{+} T \text { cells in } \\
\text { the spleen and kidney of NZBNF1 mouse (109) }\end{array}$ & & $\begin{array}{l}\text { Expanded Tfh cells in spleen of MRL/lpr } \\
\text { mouse (96) } \\
\text { Tfh cells infiltrating the brain of murine } \\
\text { neuropsychiatric lupus in MRL/pr } \\
\text { mouse (97) }\end{array}$ \\
\hline $\begin{array}{l}\text { Collagen-induced } \\
\text { arthritis mouse }\end{array}$ & $\begin{array}{l}\text { Upregulation of OX40 expression on } \mathrm{CD}^{+} \mathrm{T} \text { cells in } \\
\text { joints (110) and spleen (111) } \\
\text { Upregulation of OX40 expression on } \mathrm{CD} 4^{+} \mathrm{CD} 28^{-} \mathrm{T} \\
\text { cells in spleen (118) }\end{array}$ & $\begin{array}{l}\text { Upregulation of OX } 40 \mathrm{~L} \text { expression on APCs } \\
\text { in spleen (98) }\end{array}$ & Increased Tfh cells in the spleen (111) \\
\hline T1D mouse & $\begin{array}{l}\text { Upregulation of OX40 expression on } \mathrm{CD}^{+} \text {and } \mathrm{CD} 8^{+} \\
\mathrm{T} \text { cells in pancreatic lymph nodes and spleen of NOD } \\
\text { mouse prior to diabetes onset }(120)\end{array}$ & $\begin{array}{l}\text { Upregulation of OX40L expression on } \\
\text { dendritic cells in pancreatic lymph nodes late } \\
\text { during NOD development (120) }\end{array}$ & $\begin{array}{l}\text { Increased Tfh cells in the pancreatic } \\
\text { lymph node and the pancreas of } \\
\text { DO11xRIP-mOVA mouse (99) }\end{array}$ \\
\hline $\begin{array}{l}\text { Autoimmune } \\
\text { encephalomyelitis } \\
\text { (EAE) model }\end{array}$ & $\begin{array}{l}\text { Upregulation of OX40 expression on CD4+ } \\
\text { T cells in spleen and brain tissue }(42,106) \\
\text { OX40 expression selectively on autoantigenic CD4 } \\
\text { T cells from the inflammatory site in spinal cord or } \\
\text { brain }(111,112)\end{array}$ & $\begin{array}{l}\text { Upregulation of OX40L expression on } \\
\text { CD11 } b^{+} \text {cells and vascular endothelial cells in } \\
\text { central nerous system }(106,121)\end{array}$ & $\begin{array}{l}\text { Increased Tfh cells in ectopic lymphoid } \\
\text { structures in spinal cords (100) }\end{array}$ \\
\hline
\end{tabular}

production $(34,118,119)$ (Table 3$)$. When a blocking antiOX40L antibody was given to NOD mice at 12 weeks of age, the incidence of diabetes was reduced (120). In EAE mice, antiOX40L antibody blockade leaded to decline of clinical score and reduction of spinal cord $\mathrm{T}$ cell infiltration $(121,122)$. There are also some clinical trials targeting OX40/OX40L in development. OX40L-blocking antibodies were reported to ameliorate antigendriven Th2 responses in mouse and nonhuman primate models of asthma (123). An anti-OX40 antibody, GBR 830 in phase II study showed significant clinical improvement in patients with moderate to severe atopic dermatitis (125) (Table 3). Combined OX40L and mTOR blockade in nonhuman primate graft-versushost disease (GVHD) model prolonged survival by controlling effector $\mathrm{T}$ cell activation while preserving Treg reconstitution
(126). However, the treatment with a humanized anti-OX40L $\mathrm{mAb}$ has no effect on allergen-induced airway responses in mild asthmatic patients (124). Timing and dosing of clinical intervention may be critical for the efficacy.

\section{CONCLUSION}

Providing help for B cell development and GC reactions is the most crucial function of Tfh cells, which lead to high-affinity antibody production. Thus, increased activity of Tfh cells plays a pathogenic role in a wide range of autoimmune diseases, in both mice and humans. The differentiation of Tfh cells requires not only TCR signaling, cytokines and antigen stimulation but also costimulatory 
TABLE 3 | Therapeutic effects of OX40/OX40L blockade in vivo.

\begin{tabular}{|c|c|c|}
\hline Disease & Model & Intervention and effect \\
\hline \multirow[t]{3}{*}{$\begin{array}{l}\text { Rheumatoid arthritis } \\
\text { (RA) }\end{array}$} & $\begin{array}{l}\text { Collagen-induced arthritis } \\
(\mathrm{CIA}) \text { mouse }\end{array}$ & Anti-OX40L mAb ameliorated clinical score and suppress IFN- $\gamma$ and anti-CII Ig2a production (34) \\
\hline & CIA mouse & Anti-OX4OL mAb reduced the proinflammatory responses and ameliorated arthritis development (118) \\
\hline & ClA mouse & $\begin{array}{l}\text { Treatment with the anti-OX40 Fab'PEG blocking antibody and the OX40L:Ig fusion protein delayed the time of } \\
\text { onset of arthritis and reduced the overall clinical score (119) }\end{array}$ \\
\hline Type 1 Diabetes (T1D) & NOD mouse & Anti-OX4OL mAb given to NOD mice at 12 weeks of age prevented diabetes development (120) \\
\hline Multiple Sclerosis & EAE mouse & Anti-OX4OL antibody leaded to decline of clinical score and reduction of spinal cord T cell infiltration $(121,122)$ \\
\hline \multirow[t]{2}{*}{ Asthma } & $\begin{array}{l}\text { mouse and nonhuman } \\
\text { primate models }\end{array}$ & Anti-OX40L mAb inhibited Th2 lung inflammation (123) \\
\hline & $\begin{array}{l}\text { Mild atopic asthmatic } \\
\text { patients }\end{array}$ & $\begin{array}{l}\text { A humanized anti-OX40L mAb has no effect on allergen-induced airway responses despite partial and transient } \\
\text { reduction in total lgE and airway eosinophils (124) }\end{array}$ \\
\hline Atopic dermatitis & $\begin{array}{l}\text { Patients with moderate to } \\
\text { severe syndrome }\end{array}$ & Blocking anti-OX40 antibody showed significant clinical improvement (125) \\
\hline $\begin{array}{l}\text { Graft-versus-host } \\
\text { disease (GVHD) }\end{array}$ & nonhuman primate model & Combined OX40L and mTOR blockade prolonged survival by controlling effector T cell activation (126) \\
\hline
\end{tabular}

signals, such as ICOS/ICOSL and OX40/OX40L. As an important marker of Tfh cells, OX40 can promote Tfh generation and contribute to maintenance of Tfh and GC B cells at later times. OX40 synergizes with ICOS to maximize and prolong the Tfh response. Therefore, upregulation of OX40 and OX40L may induce abnormal activation of Tfh cells and excessive production of autoantibodies, leading to the development of autoimmune diseases.

Given that blocking OX40/OX40L signaling has shown great therapeutic effects in some mouse models of autoimmune diseases, targeting OX40/OX40L is promising as a new therapeutic approach for these diseases. However, the efficacy data of clinical trials are currently limited. Further studies are needed for clinical intervention since many factors, such as dose and time point, influence the effect. Moreover, controversial results have been obtained regarding the roles of the OX40/OX40L axis in regulation of $\mathrm{Tfh}$ responses. Whether other factors may impact the roles of OX40L in Tfh cells needs also to be further investigated.

\section{REFERENCES}

1. Schaerli P, Willimann K, Lang AB, Lipp M, Loetscher P, Moser B, et al. CXC Chemokine Receptor 5 Expression Defines Follicular Homing T Cells With B Cell Helper Function. J Exp Med (2000) 192(11):1553-62. doi: 10.1084/ jem.192.11.1553

2. Ansel KM, McHeyzer-Williams LJ, Ngo VN, McHeyzer-Williams MG, Cyster JG. In Vivo-Activated CD4 T Cells Upregulate CXC Chemokine Receptor 5 and Reprogram Their Response to Lymphoid Chemokines. J Exp Med (1999) 190(8):1123-34. doi: 10.1084/jem.190.8.1123

3. Gunn MD, Ngo VN, Ansel KM, Ekland EH, Cyster JG, Williams LT. A B-Cell-Homing Chemokine Made in Lymphoid Follicles Activates Burkitt's Lymphoma Receptor-1. Nature (1998) 391(6669):799-803. doi: 10.1038/ 35876

4. Nurieva RI, Chung Y, Hwang D, Yang XO, Kang HS, Ma L, et al. Generation of T Follicular Helper Cells Is Mediated by Interleukin-21 But Independent of T Helper 1, 2, or 17 Cell Lineages. Immunity (2008) 29(1):138-49. doi: 10.1016/j.immuni.2008.05.009

5. Chtanova T, Tangye SG, Newton R, Frank N, Hodge MR, Rolph MS, et al. T Follicular Helper Cells Express a Distinctive Transcriptional Profile, Reflecting Their Role as Non-Th1/Th2 Effector Cells That Provide Help for B Cells. J Immunol (2004) 173(1):68-78. doi: 10.4049/ jimmunol.173.1.68

\section{AUTHOR CONTRIBUTIONS}

QW and ZS organized and supervised the entire manuscript. NF contributed to the sections on Tfh cell differentiation and functions and the OX40 and OX40L molecules. XF contributed to the sections on OX40 signaling in Tfh cells and the implication of Tfh cells in autoimmune diseases. All authors contributed to the article and approved the submitted version.

\section{FUNDING}

This work was supported by grants from the National Natural Science Foundation of China (No. 81373184), the Key University Science Research Project of Jiangsu Province (20KJA180002), and the Center of Engineering Technology R\&D of the Department of Jiangsu Province Education (No. 201826).

6. Kim CH, Lim HW, Kim JR, Rott L, Hillsamer P, Butcher EC, et al. Unique Gene Expression Program of Human Germinal Center T Helper Cells. Blood (2004) 104(7):1952-60. doi: 10.1182/blood-2004-03-1206

7. Vinuesa CG, Cook MC, Angelucci C, Athanasopoulos V, Rui L, Hill KM, et al. A RING-Type Ubiquitin Ligase Family Member Required to Repress Follicular Helper T Cells and Autoimmunity. Nature (2005) 435(7041):4528. doi: $10.1038 /$ nature 03555

8. Yu D, Rao S, Tsai LM, Lee SK, He Y, Sutcliffe EL, et al. The Transcriptional Repressor Bcl-6 Directs T Follicular Helper Cell Lineage Commitment. Immunity (2009) 31(3):457-68. doi: 10.1016/j.immuni.2009.07.002

9. Dent AL, Shaffer AL, Yu X, Allman D, Staudt LM. Control of Inflammation, Cytokine Expression, and Germinal Center Formation by BCL-6. Science (1997) 276(5312):589-92. doi: 10.1126/science.276.5312.589

10. Xu W, Zhao X, Wang X, Feng H, Gou M, Jin W, et al. The Transcription Factor Tox2 Drives T Follicular Helper Cell Development Via Regulating Chromatin Accessibility. Immunity (2019) 51(5):826-39.e5. doi: 10.1016/ j.immuni.2019.10.006

11. Gigoux M, Shang J, Pak Y, Xu M, Choe J, Mak TW, et al. Inducible Costimulator Promotes Helper T-Cell Differentiation Through Phosphoinositide 3-Kinase. Proc Natl Acad Sci U S A (2009) 106 (48):20371-6. doi: 10.1073/pnas.0911573106

12. Weinstein JS, Herman EI, Lainez B, Licona-Limon P, Esplugues E, Flavell $\mathrm{R}$, et al. TFH Cells Progressively Differentiate to Regulate the Germinal 
Center Response. Nat Immunol (2016) 17(10):1197-205. doi: 10.1038/ ni. 3554

13. Victora GD, Schwickert TA, Fooksman DR, Kamphorst AO, MeyerHermann M, Dustin ML, et al. Germinal Center Dynamics Revealed by Multiphoton Microscopy With a Photoactivatable Fluorescent Reporter. Cell (2010) 143(4):592-605. doi: 10.1016/j.cell.2010.10.032

14. Ricard L, Jachiet V, Malard F, Ye Y, Stocker N, Riviere S, et al. Circulating Follicular Helper T Cells Are Increased in Systemic Sclerosis and Promote Plasmablast Differentiation Through the IL-21 Pathway Which Can Be Inhibited by Ruxolitinib. Ann Rheum Dis (2019) 78(4):539-50. doi: 10.1136/ annrheumdis-2018-214382

15. Akiba H, Takeda K, Kojima Y, Usui Y, Harada N, Yamazaki T, et al. The Role of ICOS in the CXCR5+ Follicular B Helper T Cell Maintenance. Vivo J Immunol (2005) 175(4):2340-8. doi: 10.4049/jimmunol.175.4.2340

16. Victora GD, Nussenzweig MC. Germinal Centers. Annu Rev Immunol (2012) 30:429-57. doi: 10.1146/annurev-immunol-020711-075032

17. Ozaki K, Spolski R, Ettinger R, Kim HP, Wang G, Qi CF, et al. Regulation of B Cell Differentiation and Plasma Cell Generation by IL-21, a Novel Inducer of Blimp-1 and Bcl-6. J Immunol (2004) 173(9):5361-71. doi: 10.4049/ jimmunol.173.9.5361

18. Ettinger R, Sims GP, Fairhurst AM, Robbins R, da Silva YS, Spolski R, et al. Il-21 Induces Differentiation of Human Naive and Memory B Cells Into Antibody-Secreting Plasma Cells. J Immunol (2005) 175(12):7867-79. doi: 10.4049/jimmunol.175.12.7867

19. Good KL, Bryant VL, Tangye SG. Kinetics of Human B Cell Behavior and Amplification of Proliferative Responses Following Stimulation With IL-21. J Immunol (2006) 177(8):5236-47. doi: 10.4049/jimmunol.177.8.5236

20. Bryant VL, Ma CS, Avery DT, Li Y, Good KL, Corcoran LM, et al. CytokineMediated Regulation of Human B Cell Differentiation Into Ig-secreting Cells: Predominant Role of IL-21 Produced by CXCR5+ T Follicular Helper Cells. J Immunol (2007) 179(12):8180-90. doi: 10.4049/jimmunol. 179.12.8180

21. Kuchen S, Robbins R, Sims GP, Sheng C, Phillips TM, Lipsky PE, et al. Essential Role of IL-21 in B Cell Activation, Expansion, and Plasma Cell Generation During CD4+ T Cell-B Cell Collaboration. J Immunol (2007) 179(9):5886-96. doi: 10.4049/jimmunol.179.9.5886

22. Schmitt N, Morita R, Bourdery L, Bentebibel SE, Zurawski SM, Banchereau J, et al. Human Dendritic Cells Induce the Differentiation of Interleukin-21Producing T Follicular Helper-Like Cells Through Interleukin-12. Immunity (2009) 31(1):158-69. doi: 10.1016/j.immuni.2009.04.016

23. Diehl SA, Schmidlin H, Nagasawa M, van Haren SD, Kwakkenbos MJ, Yasuda E, et al. STAT3-Mediated Up-Regulation of BLIMP1 is Coordinated With BCL6 Down-Regulation to Control Human Plasma Cell Differentiation. J Immunol (2008) 180(7):4805-15. doi: 10.4049/jimmunol. 180.7.4805

24. Spolski R, Gromer D, Leonard WJ. The Gamma C Family of Cytokines: Fine-Tuning Signals From IL-2 and IL-21 in the Regulation of the Immune Response. F1000Res (2017) 6:1872. doi: 10.12688/f1000research.12202.1

25. Renshaw BR, Fanslow WC, Armitage RJ, Campbell KA, Liggitt D, Wright B, et al. Humoral Immune Responses in CD40 Ligand-Deficient Mice. J Exp Med (1994) 180(5):1889-900. doi: 10.1084/jem.180.5.1889

26. van Essen D, Kikutani H, Gray D. CD40 Ligand-Transduced Co-Stimulation of T Cells in the Development of Helper Function. Nature (1995) 378 (6557):620-3. doi: 10.1038/378620a0

27. Whitmire JK, Slifka MK, Grewal IS, Flavell RA, Ahmed R. CD40 LigandDeficient Mice Generate a Normal Primary Cytotoxic T-Lymphocyte Response But a Defective Humoral Response to a Viral Infection. J Virol (1996) 70(12):8375-81. doi: 10.1128/JVI.70.12.8375-8381.1996

28. Schrock DC, Leddon SA, Hughson A, Miller J, Lacy-Hulbert A, Fowell DJ, et al. Pivotal Role for Alphav Integrins in Sustained Tfh Support of the Germinal Center Response for Long-Lived Plasma Cell Generation. Proc Natl Acad Sci U S A (2019) 116(10):4462-70. doi: 10.1073/pnas.1809329116

29. Mallett S, Fossum S, Barclay AN. Characterization of the MRC OX40 Antigen of Activated CD4 Positive T Lymphocytes-a Molecule Related to Nerve Growth Factor Receptor. EMBO J (1990) 9(4):1063-8. doi: 10.1002/ j.1460-2075.1990.tb08211.x

30. Latza U, Durkop H, Schnittger S, Ringeling J, Eitelbach F, Hummel M, et al. The Human OX40 Homolog: cDNA Structure, Expression and
Chromosomal Assignment of the ACT35 Antigen. Eur J Immunol (1994) 24(3):677-83. doi: 10.1002/eji.1830240329

31. Paterson DJ, Jefferies WA, Green JR, Brandon MR, Corthesy P, Puklavec M, et al. Antigens of Activated Rat T Lymphocytes Including a Molecule of 50,000 Mr Detected Only on CD4 Positive T Blasts. Mol Immunol (1987) 24 (12):1281-90. doi: 10.1016/0161-5890(87)90122-2

32. Redmond WL, Ruby CE, Weinberg AD. The Role of OX40-mediated CoStimulation in T-Cell Activation and Survival. Crit Rev Immunol (2009) 29 (3):187-201. doi: 10.1615/critrevimmunol.v29.i3.10

33. Jensen SM, Maston LD, Gough MJ, Ruby CE, Redmond WL, Crittenden M, et al. Signaling Through OX40 Enhances Antitumor Immunity. Semin Oncol (2010) 37(5):524-32. doi: 10.1053/j.seminoncol.2010.09.013

34. Yoshioka T, Nakajima A, Akiba H, Ishiwata T, Asano G, Yoshino S, et al. Contribution of OX40/OX40 Ligand Interaction to the Pathogenesis of Rheumatoid Arthritis. Eur J Immunol (2000) 30(10):2815-23. doi: 10.1002/ 1521-4141(200010)30:10<2815::AID-IMMU2815>3.0.CO;2-

35. Calderhead DM, Buhlmann JE, van den Eertwegh AJ, Claassen E, Noelle RJ, Fell HP. Cloning of Mouse Ox40: A T Cell Activation Marker That may Mediate T-B Cell Interactions. J Immunol (1993) 151(10):5261-71.

36. Zaini J, Andarini S, Tahara M, Saijo Y, Ishii N, Kawakami K, et al. OX40 Ligand Expressed by DCs Costimulates NKT and CD4+ Th Cell Antitumor Immunity in Mice. J Clin Invest (2007) 117(11):3330-8. doi: 10.1172/ JCI32693

37. Melero I, Hirschhorn-Cymerman D, Morales-Kastresana A, Sanmamed MF, Wolchok JD. Agonist Antibodies to TNFR Molecules That Costimulate T and NK Cells. Clin Cancer Res (2013) 19(5):1044-53. doi: 10.1158/10780432.CCR-12-2065

38. Miura S, Ohtani K, Numata N, Niki M, Ohbo K, Ina $\mathrm{Y}$, et al. Molecular Cloning and Characterization of a Novel Glycoprotein, gp34, That is Specifically Induced by the Human T-cell Leukemia Virus Type I Transactivator P40tax. Mol Cell Biol (1991) 11(3):1313-25. doi: 10.1128/ mcb.11.3.1313

39. Tanaka Y, Inoi T, Tozawa H, Yamamoto N, Hinuma Y. A Glycoprotein Antigen Detected With New Monoclonal Antibodies on the Surface of Human Lymphocytes Infected With Human T-Cell Leukemia Virus Type-I (HTLV-I). Int J Cancer (1985) 36(5):549-55. doi: 10.1002/ijc.2910360506

40. Stuber E, Neurath M, Calderhead D, Fell HP, Strober W. Cross-linking of OX40 Ligand, a Member of the TNF/NGF Cytokine Family, Induces Proliferation and Differentiation in Murine Splenic B Cells. Immunity (1995) 2(5):507-21. doi: 10.1016/1074-7613(95)90031-4

41. Ohshima Y, Tanaka Y, Tozawa H, Takahashi Y, Maliszewski C, Delespesse G, et al. Expression and Function of OX40 Ligand on Human Dendritic Cells. J Immunol (1997) 159(8):3838-48.

42. Weinberg AD, Wegmann KW, Funatake C, Whitham RH. Blocking Ox-40/ OX-40 Ligand Interaction In Vitro and In Vivo Leads to Decreased T Cell Function and Amelioration of Experimental Allergic Encephalomyelitis. J Immunol (1999) 162(3):1818-26.

43. Prell RA, Evans DE, Thalhofer C, Shi T, Funatake C, Weinberg AD. OX40Mediated Memory T Cell Generation is TNF Receptor-Associated Factor 2 Dependent. J Immunol (2003) 171(11):5997-6005. doi: 10.4049/jimmunol. 171.11.5997

44. So T, Salek-Ardakani S, Nakano H, Ware CF, Croft M. TNF ReceptorAssociated Factor 5 Limits the Induction of Th2 Immune Responses. J Immunol (2004) 172(7):4292-7. doi: 10.4049/jimmunol.172.7.4292

45. Hauer J, Puschner S, Ramakrishnan P, Simon U, Bongers M, Federle C, et al. TNF Receptor (TNFR)-Associated Factor (TRAF) 3 Serves as an Inhibitor of TRAF2/5-Mediated Activation of the Noncanonical NF-kappaB Pathway by TRAF-binding Tnfrs. Proc Natl Acad Sci U S A (2005) 102(8):2874-9. doi: $10.1073 /$ pnas. 0500187102

46. Kawamata S, Hori T, Imura A, Takaori-Kondo A, Uchiyama T. Activation of OX40 Signal Transduction Pathways Leads to Tumor Necrosis Factor Receptor-Associated Factor (TRAF) 2- and TRAF5-Mediated NF-Kappab Activation. J Biol Chem (1998) 273(10):5808-14. doi: 10.1074/ jbc.273.10.5808

47. Arch RH, Thompson CB. 4-1BB and Ox40 are Members of a Tumor Necrosis Factor (TNF)-Nerve Growth Factor Receptor Subfamily That Bind TNF Receptor-Associated Factors and Activate Nuclear Factor kappaB. Mol Cell Biol (1998) 18(1):558-65. doi: 10.1128/mcb.18.1.558 
48. Kinnear G, Wood KJ, Fallah-Arani F, Jones ND. A Diametric Role for OX40 in the Response of Effector/Memory CD4+ T Cells and Regulatory T Cells to Alloantigen. J Immunol (2013) 191(3):1465-75. doi: 10.4049/jimmunol.1300553

49. Webb GJ, Hirschfield GM, Lane PJ. OX40, OX40L and Autoimmunity: A Comprehensive Review. Clin Rev Allergy Immunol (2016) 50(3):312-32. doi: 10.1007/s12016-015-8498-3

50. Gramaglia I, Weinberg AD, Lemon M, Croft M. Ox-40 Ligand: A Potent Costimulatory Molecule for Sustaining Primary CD4 T Cell Responses. J Immunol (1998) 161(12):6510-7.

51. Sun G, Jin H, Zhang C, Meng H, Zhao X, Wei D, et al. Ox40 Regulates Both Innate and Adaptive Immunity and Promotes Nonalcoholic Steatohepatitis. Cell Rep (2018) 25(13):3786-99.e4. doi: 10.1016/j.celrep.2018.12.006

52. Krause P, Bruckner M, Uermosi C, Singer E, Groettrup M, Legler DF, et al. Prostaglandin E(2) Enhances T-cell Proliferation by Inducing the Costimulatory Molecules OX40L, CD70, and 4-1BBL on Dendritic Cells. Blood (2009) 113(11):2451-60. doi: 10.1182/blood-2008-05-157123

53. Pattarini L, Trichot C, Bogiatzi S, Grandclaudon M, Meller S, Keuylian Z, et al. TSLP-Activated Dendritic Cells Induce Human T Follicular Helper Cell Differentiation Through OX40-Ligand. J Exp Med (2017) 214(5):1529-46. doi: $10.1084 /$ jem. 20150402

54. Maxwell JR, Yadav R, Rossi RJ, Ruby CE, Weinberg AD, Aguila HL, et al. Il18 Bridges Innate and Adaptive Immunity Through IFN-gamma and the CD134 Pathway. J Immunol (2006) 177(1):234-45. doi: 10.4049/jimmunol. 177.1.234

55. Cui D, Lv Y, Yuan X, Ruan G, Zhang Y, Yan C, et al. Increased Expressions of OX40 and OX40 Ligand in Patients With Primary Immune Thrombocytopenia. J Immunol Res (2019) 2019:6804806. doi: 10.1155/ 2019/6804806

56. Rogers PR, Song J, Gramaglia I, Killeen N, Croft M. OX40 Promotes Bcl-xL and Bcl-2 Expression and is Essential for Long-Term Survival of CD4 T Cells. Immunity (2001) 15(3):445-55. doi: 10.1016/s1074-7613(01)00191-1

57. Song J, Salek-Ardakan S, Rogers PR, Cheng M, Van Parijs L, Croft M. The Costimulation-Regulated Duration of PKB Activation Controls T Cell Longevity. Nat Immunol (2004) 5(2):150-8. doi: 10.1038/ni1030

58. Lane P. Role of OX40 Signals in Coordinating CD4 T Cell Selection, Migration, and Cytokine Differentiation in T Helper (Th)1 and Th2 Cells. J Exp Med (2000) 191(2):201-6. doi: 10.1084/jem.191.2.201

59. Xiao X, Balasubramanian S, Liu W, Chu X, Wang H, Taparowsky EJ, et al. OX40 Signaling Favors the Induction of $\mathrm{T}(\mathrm{H}) 9$ Cells and Airway Inflammation. Nat Immunol (2012) 13(10):981-90. doi: 10.1038/ni.2390

60. Takeda I, Ine S, Killeen N, Ndhlovu LC, Murata K, Satomi S, et al. Distinct Roles for the OX40-OX40 Ligand Interaction in Regulatory and Nonregulatory T Cells. J Immunol (2004) 172(6):3580-9. doi: 10.4049/ jimmunol.172.6.3580

61. Zhao X, Wei YQ, Kariya Y, Teshigawara K, Uchida A. Accumulation of Gamma/Delta T Cells in Human Dysgerminoma and Seminoma: Roles in Autologous Tumor Killing and Granuloma Formation. Immunol Invest (1995) 24(4):607-18. doi: 10.3109/08820139509066861

62. Gavin MA, Clarke SR, Negrou E, Gallegos A, Rudensky A. Homeostasis and Anergy of CD4(+)CD25(+) Suppressor T Cells. Vivo Nat Immunol (2002) 3 (1):33-41. doi: 10.1038/ni743

63. Walker LS, Gulbranson-Judge A, Flynn S, Brocker T, Lane PJ. Costimulation and Selection for T-Cell Help for Germinal Centres: The Role of CD28 and OX40. Immunol Today (2000) 21(7):333-7. doi: 10.1016/ s0167-5699(00)01636-4

64. Yuan JS, Feng YT, Wang F, Gong WY, Di DL, Ren J, et al. [Establishment of the Transfected Cell Line Expressing the Mouse OX40 Gene and Its Potency to Induce Differentiation of B Cells]. Xi Bao Yu Fen Zi Mian Yi Xue Za Zhi (2005) 21(6):767-70.

65. Morimoto S, Kanno Y, Tanaka Y, Tokano Y, Hashimoto H, Jacquot S, et al. CD134L Engagement Enhances Human B Cell Ig Production: CD154/CD40, CD70/CD27, and CD134/CD134L Interactions Coordinately Regulate T Cell-Dependent B Cell Responses. J Immunol (2000) 164(8):4097-104. doi: 10.4049/jimmunol.164.8.4097

66. Adam L, Zoldan K, Hofmann M, Schultheiss M, Bettinger D, NeumannHaefelin C, et al. Follicular T Helper Cell Signatures in Primary Biliary Cholangitis and Primary Sclerosing Cholangitis. Hepatol Commun (2018) 2 (9):1051-63. doi: 10.1002/hep4.1226
67. Kurata I, Matsumoto I, Ohyama A, Osada A, Ebe H, Kawaguchi H, et al. Potential Involvement of OX40 in the Regulation of Autoantibody Sialylation in Arthritis. Ann Rheum Dis (2019) 78(11):1488-96. doi: 10.1136/ annrheumdis-2019-215195

68. Jiang H, Cui N, Yang L, Liu C, Yue L, Guo L, et al. Altered Follicular Helper T Cell Impaired Antibody Production in a Murine Model of Myelodysplastic Syndromes. Oncotarget (2017) 8(58):98270-79. doi: 10.18632/ oncotarget. 21548

69. Tahiliani V, Hutchinson TE, Abboud G, Croft M, Salek-Ardakani S. OX40 Cooperates With ICOS to Amplify Follicular Th Cell Development and Germinal Center Reactions During Infection. J Immunol (2017) 198(1):21828. doi: 10.4049/jimmunol.1601356

70. Vogel KU, Edelmann SL, Jeltsch KM, Bertossi A, Heger K, Heinz GA, et al. Roquin Paralogs 1 and 2 Redundantly Repress the Icos and Ox40 Costimulator mRNAs and Control Follicular Helper T Cell Differentiation. Immunity (2013) 38(4):655-68. doi: 10.1016/j.immuni. 2012.12.004

71. Flynn S, Toellner KM, Raykundalia C, Goodall M, Lane P. Cd4 T Cell Cytokine Differentiation: The B Cell Activation Molecule, OX40 Ligand, Instructs CD4 T Cells to Express Interleukin 4 and Upregulates Expression of the Chemokine Receptor, Blr-1. J Exp Med (1998) 188(2):297-304. doi: $10.1084 /$ jem.188.2.297

72. Jacquemin C, Schmitt N, Contin-Bordes C, Liu Y, Narayanan P, Seneschal J, et al. Ox40 Ligand Contributes to Human Lupus Pathogenesis by Promoting T Follicular Helper Response. Immunity (2015) 42(6):1159-70. doi: 10.1016/ j.immuni.2015.05.012

73. Fillatreau S, Gray D. T Cell Accumulation in B Cell Follicles Is Regulated by Dendritic Cells and Is Independent of B Cell Activation. J Exp Med (2003) 197(2):195-206. doi: 10.1084/jem.20021750

74. Li Y, Zhao L, Sui B, Luo Z, Zhang Y, Wang Y, et al. Recombinant Rabies Virus Overexpressing Ox40-Ligand Enhances Humoral Immune Responses by Increasing $\mathrm{T}$ Follicular Helper Cells and Germinal Center B Cells. Vaccines (Basel) (2020) 8(1). doi: 10.3390/vaccines8010144

75. Cortini A, Ellinghaus U, Cortini TH, Cunninghame DS, Graham M, Botto TJ. B Cell OX40L Supports T Follicular Helper Cell Development and Contributes to SLE Pathogenesis. Ann Rheum Dis (2017) 76(12):2095-103. doi: 10.1136/annrheumdis-2017-211499

76. So T, Soroosh P, Eun SY, Altman A, Croft M. Antigen-Independent Signalosome of CARMA1, Pkctheta, and TNF Receptor-Associated Factor 2 (TRAF2) Determines NF-kappaB Signaling in T Cells. Proc Natl Acad Sci U S A (2011) 108(7):2903-8. doi: 10.1073/pnas.1008765108

77. Croft M. Control of Immunity by the TNFR-related Molecule OX40 (Cd134). Annu Rev Immunol (2010) 28:57-78. doi: 10.1146/annurev-immunol030409-101243

78. So T, Song J, Sugie K, Altman A, Croft M. Signals From OX40 Regulate Nuclear Factor of Activated T Cells C1 and T Cell Helper 2 Lineage Commitment. Proc Natl Acad Sci U S A (2006) 103(10):3740-5. doi: 10.1073/ pnas.0600205103

79. So T, Croft M. Regulation of PI-3-Kinase and Akt Signaling in T Lymphocytes and Other Cells by TNFR Family Molecules. Front Immunol (2013) 4:139. doi: 10.3389/fimmu.2013.00139

80. So T, Choi H, Croft M. OX40 Complexes With Phosphoinositide 3-Kinase and Protein Kinase B (PKB) to Augment TCR-dependent PKB Signaling. J Immunol (2011) 186(6):3547-55. doi: 10.4049/jimmunol.1003156

81. Serre K, Mohr E, Benezech C, Bird R, Khan M, Caamano JH, et al. Selective Effects of NF-kappaB1 Deficiency in CD4(+) T Cells on Th2 and TFh Induction by Alum-Precipitated Protein Vaccines. Eur J Immunol (2011) 41 (6):1573-82. doi: 10.1002/eji.201041126

82. Deenick EK, Chan A, Ma CS, Gatto D, Schwartzberg PL, Brink R, et al. Follicular Helper T Cell Differentiation Requires Continuous Antigen Presentation That Is Independent of Unique B Cell Signaling. Immunity (2010) 33(2):241-53. doi: 10.1016/j.immuni.2010.07.015

83. Tubo NJ, Pagan AJ, Taylor JJ, Nelson RW, Linehan JL, Ertelt JM, et al. Single Naive CD4+ T Cells From a Diverse Repertoire Produce Different Effector Cell Types During Infection. Cell (2013) 153(4):785-96. doi: 10.1016/ j.cell.2013.04.007

84. Fazilleau N, McHeyzer-Williams LJ, Rosen H, McHeyzer-Williams MG. The Function of Follicular Helper T Cells Is Regulated by the Strength of T Cell 
Antigen Receptor Binding. Nat Immunol (2009) 10(4):375-84. doi: 10.1038/ ni. 1704

85. Preite S, Huang B, Cannons JL, McGavern DB, Schwartzberg PL. PI3K Orchestrates T Follicular Helper Cell Differentiation in a Context Dependent Manner: Implications for Autoimmunity. Front Immunol (2018) 9:3079. doi: 10.3389/fimmu.2018.03079

86. Martinez GJ, Hu JK, Pereira RM, Crampton JS, Togher S, Bild N, et al. Cutting Edge: Nfat Transcription Factors Promote the Generation of Follicular Helper T Cells in Response to Acute Viral Infection. J Immunol (2016) 196(5):2015-9. doi: 10.4049/jimmunol.1501841

87. Viisanen T, Ihantola EL, Nanto-Salonen K, Hyoty H, Nurminen N, Selvenius J, et al. Circulating CXCR5+PD-1+ICOS+ Follicular T Helper Cells are Increased Close to the Diagnosis of Type 1 Diabetes in Children With Multiple Autoantibodies. Diabetes (2017) 66(2):437-47. doi: 10.2337/ db16-0714

88. Ferreira RC, Simons HZ, Thompson WS, Cutler AJ, Dopico XC, Smyth DJ, et al. Il-21 Production by CD4+ Effector T Cells and Frequency of Circulating Follicular Helper T Cells are Increased in Type 1 Diabetes Patients. Diabetologia (2015) 58(4):781-90. doi: 10.1007/s00125-015-3509-8

89. Xu X, Shi Y, Cai Y, Zhang Q, Yang F, Chen H, et al. Inhibition of Increased Circulating Tfh Cell by anti-CD20 Monoclonal Antibody in Patients With Type 1 Diabetes. PloS One (2013) 8(11):e79858. doi: 10.1371/journal.pone.0079858

90. Liu Y, Yuan X, Li X, Cui D, Xie J. Constitutive Changes in Circulating Follicular Helper T Cells and Their Subsets in Patients With Graves' Disease. J Immunol Res (2018) 2018:8972572. doi: 10.1155/2018/8972572

91. Gharibi T, Hosseini A, Marofi F, Oraei M, Jahandideh S, AbdollahpourAlitappeh M, et al. Corrigendum to "Il-21 and IL-21-Producing T Cells are Involved in Multiple Sclerosis Severity and Progression. Immunol Lett (2021) 216(2019):12-20. doi: 10.1016/j.imlet.2020.12.013

92. Puthenparampil M, Zito A, Pantano G, Federle L, Stropparo E, Miante S, et al. Peripheral Imbalanced TFH/TFR Ratio Correlates With Intrathecal IgG Synthesis in Multiple Sclerosis at Clinical Onset. Mult Scler (2019) 25 (7):918-26. doi: 10.1177/1352458518779951

93. Li Y, Guptill JT, Russo MA, Howard JF Jr, Massey JM, Juel VC, et al. Imbalance in T Follicular Helper Cells Producing IL-17 Promotes ProInflammatory Responses in MuSK Antibody Positive Myasthenia Gravis. $J$ Neuroimmunol (2020) 345:577279. doi: 10.1016/j.jneuroim.2020.577279

94. Maehara T, Moriyama M, Hayashida JN, Tanaka A, Shinozaki S, Kubo Y, et al. Selective Localization of T Helper Subsets in Labial Salivary Glands From Primary Sjogren's Syndrome Patients. Clin Exp Immunol (2012) 169 (2):89-99. doi: 10.1111/j.1365-2249.2012.04606.x

95. Jin L, Yu D, Li X, Yu N, Li X, Wang Y, et al. CD4+CXCR5+ Follicular Helper T Cells in Salivary Gland Promote B Cells Maturation in Patients With Primary Sjogren's Syndrome. Int J Clin Exp Pathol (2014) 7(5):1988-96.

96. Yang X, Yang J, Chu Y, Wang J, Guan M, Zhu X, et al. T Follicular Helper Cells Mediate Expansion of Regulatory B Cells Via IL-21 in Lupus-prone MRL/Lpr Mice. PloS One (2013) 8(4):e62855. doi: 10.1371/journal. pone. 0062855

97. Jain S, Stock A, Macian F, Putterman C. A Distinct T Follicular Helper Cell Subset Infiltrates the Brain in Murine Neuropsychiatric Lupus. Front Immunol (2018) 9:487. doi: 10.3389/fimmu.2018.00487

98. Cao G, Chi S, Wang X, Sun J, Zhang Y. Cd4+Cxcr5+Pd-1+ T Follicular Helper Cells Play a Pivotal Role in the Development of Rheumatoid Arthritis. Med Sci Monit (2019) 25:3032-40. doi: 10.12659/MSM.914868

99. Kenefeck R, Wang CJ, Kapadi T, Wardzinski L, Attridge K, Clough LE, et al. Follicular Helper T Cell Signature in Type 1 Diabetes. J Clin Invest (2015) 125(1):292-303. doi: 10.1172/JCI76238

100. Guo J, Zhao C, Wu F, Tao L, Zhang C, Zhao D, et al. T Follicular Helper-Like Cells are Involved in the Pathogenesis of Experimental Autoimmune Encephalomyelitis. Front Immunol (2018) 9:944. doi: 10.3389/fimmu. 2018.00944

101. Wang L, Zhang Y, Zhu M, Feng J, Han J, Zhu J, et al. Effects of Follicular Helper T Cells and Inflammatory Cytokines on Myasthenia Gravis. Curr Mol Med (2019) 19(10):739-45. doi: 10.2174/1566524019666190827162615

102. Kim SJ, Lee K, Diamond B. Follicular Helper T Cells in Systemic Lupus Erythematosus. Front Immunol (2018) 9:1793. doi: 10.3389/fimmu.2018.01793

103. Li XY, Wu ZB, Ding J, Zheng ZH, Li XY, Chen LN, et al. Role of the Frequency of Blood CD4(+) Cxcr5(+) Ccr6(+) T Cells in Autoimmunity in
Patients With Sjogren's Syndrome. Biochem Biophys Res Commun (2012) 422(2):238-44. doi: 10.1016/j.bbrc.2012.04.133

104. Szypowska A, Stelmaszczyk-Emmel A, Demkow U, Luczynski W. High Expression of OX40 (CD134) and 4-1BB (CD137) Molecules on CD4(+) CD25(high) Cells in Children With Type 1 Diabetes. Adv Med Sci (2014) 59 (1):39-43. doi: 10.1016/j.advms.2013.07.003

105. Bornsen L, Christensen JR, Ratzer R, Oturai AB, Sorensen PS, Sondergaard $\mathrm{HB}$, et al. Effect of Natalizumab on Circulating CD4+ T-Cells in Multiple Sclerosis. PloS One (2012) 7(11):e47578. doi: 10.1371/journal.pone.0047578

106. Carboni S, Aboul-Enein F, Waltzinger C, Killeen N, Lassmann H, PenaRossi C, et al. CD134 Plays a Crucial Role in the Pathogenesis of EAE and is Upregulated in the CNS of Patients With Multiple Sclerosis. J Neuroimmunol (2003) 145(1-2):1-11. doi: 10.1016/j.jneuroim.2003.07.001

107. Xiaoyan Z, Pirskanen R, Malmstrom V. Lefvert AK. Expression of OX40 (CD134) on CD4+ T-Cells From Patients With Myasthenia Gravis. Clin Exp Immunol (2006) 143(1):110-6. doi: 10.1111/j.1365-2249.2005.02955.x

108. Zhu R, Jiang J, Wang T, Xu T, Wu M, Liu C, et al. [Expressions and Clinical Significance of OX40 and OX40L in Peripheral Blood of Patients With Primary Sjogren's Syndrome]. Xi Bao Yu Fen Zi Mian Yi Xue Za Zhi (2013) 29(8):862-5

109. Sitrin J, Suto E, Wuster A, Eastham-Anderson J, Kim JM, Austin CD, et al. The Ox40/Ox40 Ligand Pathway Promotes Pathogenic Th Cell Responses, Plasmablast Accumulation, and Lupus Nephritis in NZB/W F1 Mice. J Immunol (2017) 199(4):1238-49. doi: 10.4049/jimmunol.1700608

110. Saijo S, Asano M, Horai R, Yamamoto H, Iwakura Y. Suppression of Autoimmune Arthritis in Interleukin-1-Deficient Mice in Which T Cell Activation Is Impaired Due to Low Levels of CD40 Ligand and OX40 Expression on T Cells. Arthritis Rheumatol (2002) 46(2):533-44. doi: 10.1002/art.10172

111. Huang Y, Pan C, Liu Y, Lin S, Zhan Y, Zhang Y, et al. Immune Function and Mechanism of Costimulating Molecules PD-1 and OX40 in Rheumatoid Arthritis. J Interferon Cytokine Res (2020) 40(11):530-39. doi: 10.1089/ jir.2020.0010

112. Buenafe AC, Weinberg AD, Culbertson NE, Vandenbark AA, Offner H. V Beta CDR3 Motifs Associated With BP Recognition are Enriched in OX-40+ Spinal Cord T Cells of Lewis Rats With EAE. J Neurosci Res (1996) 44 (6):562-7. doi: 10.1002/(SICI) 1097-4547(19960615)44:6<562::AIDJNR6>3.0.CO;2-9

113. Farres MN, Al-Zifzaf DS, Aly AA, Abd Raboh NM. OX40/OX40L in Systemic Lupus Erythematosus: Association With Disease Activity and Lupus Nephritis. Ann Saudi Med (2011) 31(1):29-34. doi: 10.4103/02564947.75775

114. Zhou YB, Ye RG, Li YJ, Xie CM, Wu YH. Effect of anti-CD134L mAb and CTLA4Ig on ConA-Induced Proliferation, Th Cytokine Secretion, and AntidsDNA Antibody Production in Spleen Cells From Lupus-Prone BXSB Mice. Autoimmunity (2008) 41(5):395-404. doi: 10.1080/08916930802002240

115. Bartalena L. Diagnosis and Management of Graves Disease: A Global Overview. Nat Rev Endocrinol (2013) 9(12):724-34. doi: 10.1038/nrendo. 2013.193

116. Hussain YS, Hookham JC, Allahabadia A, Balasubramanian SP. Epidemiology, Management and Outcomes of Graves' Disease-Real Life Data. Endocrine (2017) 56(3):568-78. doi: 10.1007/s12020-017-1306-5

117. Wang Q, Shi BM, Xie F, Fu ZY, Chen YJ, An JN, et al. Enhancement of CD4 (+) T Cell Response and Survival Via Coexpressed OX40/OX40L in Graves' Disease. Mol Cell Endocrinol (2016) 430:115-24. doi: 10.1016/ j.mce.2016.04.008

118. Jiang J, Liu C, Liu M, Shen Y, Hu X, Wang Q, et al. OX40 Signaling is Involved in the Autoactivation of $\mathrm{CD} 4(+) \mathrm{CD} 28(-) \mathrm{T}$ Cells and Contributes to the Pathogenesis of Autoimmune Arthritis. Arthritis Res Ther (2017) 19 (1):67. doi: 10.1186/s13075-017-1261-9

119. Gwyer Findlay E, Danks L, Madden J, Cavanagh MM, McNamee K, McCann F, et al. OX40L Blockade is Therapeutic in Arthritis, Despite Promoting Osteoclastogenesis. Proc Natl Acad Sci U S A (2014) 111(6):2289-94. doi: 10.1073/pnas.1321071111

120. Pakala SV, Bansal-Pakala P, Halteman BS, Croft M. Prevention of Diabetes in NOD Mice at a Late Stage by Targeting OX40/OX40 Ligand Interactions. Eur J Immunol (2004) 34(11):3039-46. doi: 10.1002/eji.200425141

121. Nohara C, Akiba H, Nakajima A, Inoue A, Koh CS, Ohshima H, et al. Amelioration of Experimental Autoimmune Encephalomyelitis With Anti- 
OX40 Ligand Monoclonal Antibody: A Critical Role for OX40 Ligand in Migration, But Not Development, of Pathogenic T Cells. J Immunol (2001) 166(3):2108-15. doi: 10.4049/jimmunol.166.3.2108

122. Elyaman W, Kivisakk P, Reddy J, Chitnis T, Raddassi K, Imitola J, et al. Distinct Functions of Autoreactive Memory and Effector CD4+ T Cells in Experimental Autoimmune Encephalomyelitis. Am J Pathol (2008) 173 (2):411-22. doi: 10.2353/ajpath.2008.080142

123. Seshasayee D, Lee WP, Zhou M, Shu J, Suto E, Zhang J, et al. In Vivo Blockade of OX40 Ligand Inhibits Thymic Stromal Lymphopoietin Driven Atopic Inflammation. J Clin Invest (2007) 117(12):3868-78. doi: 10.1172/ JCI33559

124. Gauvreau GM, Boulet LP, Cockcroft DW, FitzGerald JM, Mayers I, Carlsten $\mathrm{C}$, et al. OX40L Blockade and Allergen-Induced Airway Responses in Subjects With Mild Asthma. Clin Exp Allergy (2014) 44(1):29-37. doi: 10.1111/cea.12235

125. Guttman-Yassky E, Pavel AB, Zhou L, Estrada YD, Zhang N, Xu H, et al. GBR 830, an Anti-OX40, Improves Skin Gene Signatures and Clinical Scores in Patients With Atopic Dermatitis. J Allergy Clin Immunol (2019) 144 (2):482-93.e7. doi: 10.1016/j.jaci.2018.11.053

126. Tkachev V, Furlan SN, Watkins B, Hunt DJ, Zheng HN, PanoskaltsisMortari A, et al. Combined OX40L and mTOR Blockade Controls Effector T Cell Activation While Preserving Treg Reconstitution After Transplant. Sci Transl Med (2017) 9(408). doi: 10.1126/scitranslmed.aan3085

Conflict of Interest: The authors declare that the research was conducted in the absence of any commercial or financial relationships that could be construed as a potential conflict of interest.

Copyright (๑) $2021 \mathrm{Fu}$, Xie, Sun and Wang. This is an open-access article distributed under the terms of the Creative Commons Attribution License (CC BY). The use, distribution or reproduction in other forums is permitted, provided the original author(s) and the copyright owner(s) are credited and that the original publication in this journal is cited, in accordance with accepted academic practice. No use, distribution or reproduction is permitted which does not comply with these terms. 